\title{
Assessment of Soil Organic Carbon Stock of Churia Broad Leaved Forest of Nawalpur District, Nepal
}

\author{
Bharat Mohan Adhikari*1, Pramod Ghimire ${ }^{1}$ \\ ${ }^{1}$ Faculty of Forestry, Agriculture and Forestry University, Hetauda, Nepal \\ *Corresponding author (Email: bemabharat@gmail.com)
}

How to cite this paper: Adhikari, B.M. and Ghimire, P. (2019). Assessment of Soil Organic Carbon Stock of Churia Broad Leaved Forest of Nawalpur District, Nepal. Grassroots Journal of Natural Resources, 2(1-2): 45-52. Doi:

https://doi.org/10.33002/nr2581.6853.02125

Received: 29 April 2019

Reviewed: 02 May 2019

Provisionally Accepted: 10 May 2019

Revised: 17 May 2019

Finally Accepted: 20 May 2019

Published: 20 June 2019

Copyright $(92019$ by author(s) and

The Grassroots Institute.

This work is licensed under the Creative Commons Attribution International License (CC BY 4.0).

http://creativecommons.org/licenses/by/4.0/

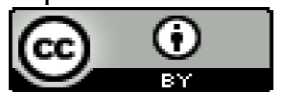

Open Access

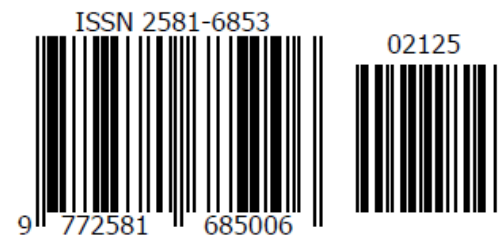

\begin{abstract}
The present article is based on the study carried out to quantify aspect wise variation in Soil Organic Carbon (SOC) stock of Churia broad leaved forest in Bhedawari Community Forest of Nawalpur district, Nepal. The total amount of SOC stock in upto $30 \mathrm{~cm}$ soil depth in Bhedawari Community Forest was found to be $33.91 \mathrm{t} / \mathrm{ha}$. Aspect had made significant difference upon SOC stock with $\mathrm{p}$ value of $0.002(\mathrm{p}<0.05)$. The total SOC was higher in the northern aspect $(36.83 \pm 1.34 \mathrm{t} / \mathrm{ha})$ than in the southern aspect $(30.98 \pm 1.22 \mathrm{t} / \mathrm{ha})$. Hence, soil carbon sequestration through community managed forest is a good strategy to mitigate the increasing concentration of atmospheric $\mathrm{CO}_{2}$.
\end{abstract}

\section{Keywords}

Soil Organic Carbon; Community Forest; Aspect 
Doi: https://doi.org/10.33002/nr2581.6853.02125

\section{Introduction}

The interaction between climate change and the global carbon cycle is an important aspect of the global environmental changes (Parry et al., 2007). Soil is the largest pool of terrestrial organic carbon in biosphere, storing more carbon. Therefore, the Soil Organic Carbon (SOC) stock has an irreplaceable function in mitigating climate change as a key component of the biosphere carbon cycle. Meaning that changes in Soil Organic Carbon (SOC) content significantly influence climate change, and a slight change in the SOC stocks can have a considerable effect on atmospheric carbon dioxide concentration, contributing to climate change (Jobbágy and Jackson, 2000).

Soil, being the largest carbon reservoir of the terrestrial carbon cycle, has three times more carbon than in the world's vegetation. The soils hold double the amount of carbon that is present in the atmosphere (Sheikh, Kumar and Bussmann, 2009). The amount of stored SOC is the net balance between carbon inputs from plant production and losses through decomposition and leaching. Hence, depending upon carbon fluxes, the soil can either be a source or sink for atmospheric $\mathrm{CO}_{2}$ (Schrumpf et al., 2011). The stability and distribution of SOC in the soil profile is influenced by biotic controls such as the abundance and vigor of faunal, microbial and plant species, as well as environmental controls like temperature, moisture and soil texture (Lorenz and Lal, 2005). Carbon emissions from deforestation account for an estimated $20 \%$ of global carbon emissions (Parry et al., 2007), second only to that produced by fossil fuel combustion (Campbell et al., 2008).

Nepal ranked $4^{\text {th }}$ most vulnerable country in the world in terms of climate change (Maplecroft, 2010 cited in MoEnv, 2012), and the main issue is to mitigate the climate change for the betterment of the environment and sustainable development. Nepal's Department of Forest Research and Survey (DFRS) in 2015 reported that Nepal's average organic carbon in soil, litter and debris, and tree component ( $\geq 10 \mathrm{~cm} \mathrm{DBH})$ are $67.14 \mathrm{t} / \mathrm{ha}, 1.19 \mathrm{t} / \mathrm{ha}$ and $108.88 \mathrm{t} / \mathrm{ha}$, respectively. The highest soil organic carbon stock (114.03 t/ha) was estimated in High ${ }^{1}$ Mountain and High $\mathrm{Himal}^{2}$ regions. SOC was the lowest in Churia region with an average of $31.44 \mathrm{t} / \mathrm{ha}$. The results from Middle Mountains $^{3}$ region showed an average SOC stock of $54.33 \mathrm{t} / \mathrm{ha}$. SOC stock in the forests of the Terai $^{4}$ was found to be slightly higher than in Churia ${ }^{5}$. To successfully reduce greenhouse gas emissions from land cover change, effective strategies for protecting natural habitats are needed. Thus, assessment of SOC is important for carbon budgeting, designing appropriate carbon sequestration strategies and enhancing our understanding of biogeochemical cycles. The aim of this article is, therefore, to investigate how SOC in the profiles varied under different aspect in community managed Churia broad-leaved forest.

\footnotetext{
${ }^{1}$ High Mountains: The region is characterized by the rugged landscape and very steep slopes and elevation varies from $543 \mathrm{~m}$ in the river valley floor to $4951 \mathrm{~m}$ above mean sea level.

${ }^{2}$ High Himal: This region includes the highest Himalayan massifs and elevation ranges from 1,960 $\mathrm{m}$ to $8,848 \mathrm{~m}$ above mean sea level.

${ }^{3}$ Middle Mountains: This region lies north of Churia along the southern flanks of the Himalayas and elevation varies from $110 \mathrm{~m}$ in the lower river valleys to $3,300 \mathrm{~m}$ above mean sea level.

${ }^{4}$ Terai: It consists of gently sloping recent and post-Pleistocene alluvial deposits, which form a piedmont plain south of the Himalayas. Its elevation varies from $63 \mathrm{~m}$ to $330 \mathrm{~m}$ above mean sea level.

${ }^{5}$ Churia: Churia region is the youngest mountain range in the Himalayas. Just north of the Terai, it runs the entire length of southern Nepal, from east to west, skirting the southern flanks of the Himalayas. The elevation of Churia varies from 93 to $1,955 \mathrm{~m}$ above mean sea level.
} 
Doi: https://doi.org/10.33002/nr2581.6853.02125

\section{Materials and Methods}

\section{Study Area}

The research was carried out in Bhedawari Community Forest of Churia region. It is situated in Gaindakot Municipality ward number 11 and 12, an eastern part of Nawalpur district in the Gandaki Province of Nepal. It lies between $27^{\circ} 42^{\prime} \mathrm{N}$ latitude and $84^{\circ} 18^{\prime} \mathrm{E}$ longitude. It is about 14 kilometers west from Narayangadh, Chitwan district. The study area experiences tropical climate with altitudinal range from 200 to $750 \mathrm{~m}$ from mean sea level (Figure 1). Soil is of reddish-brown type. It is the area having a natural broad-leaved forest dominated by Shorea robusta (Sal) with other associates such as Terminalia tomentosa (Saj), Adina cordifolia (Karma), Semecarpus anacardum (Valayo), etc.

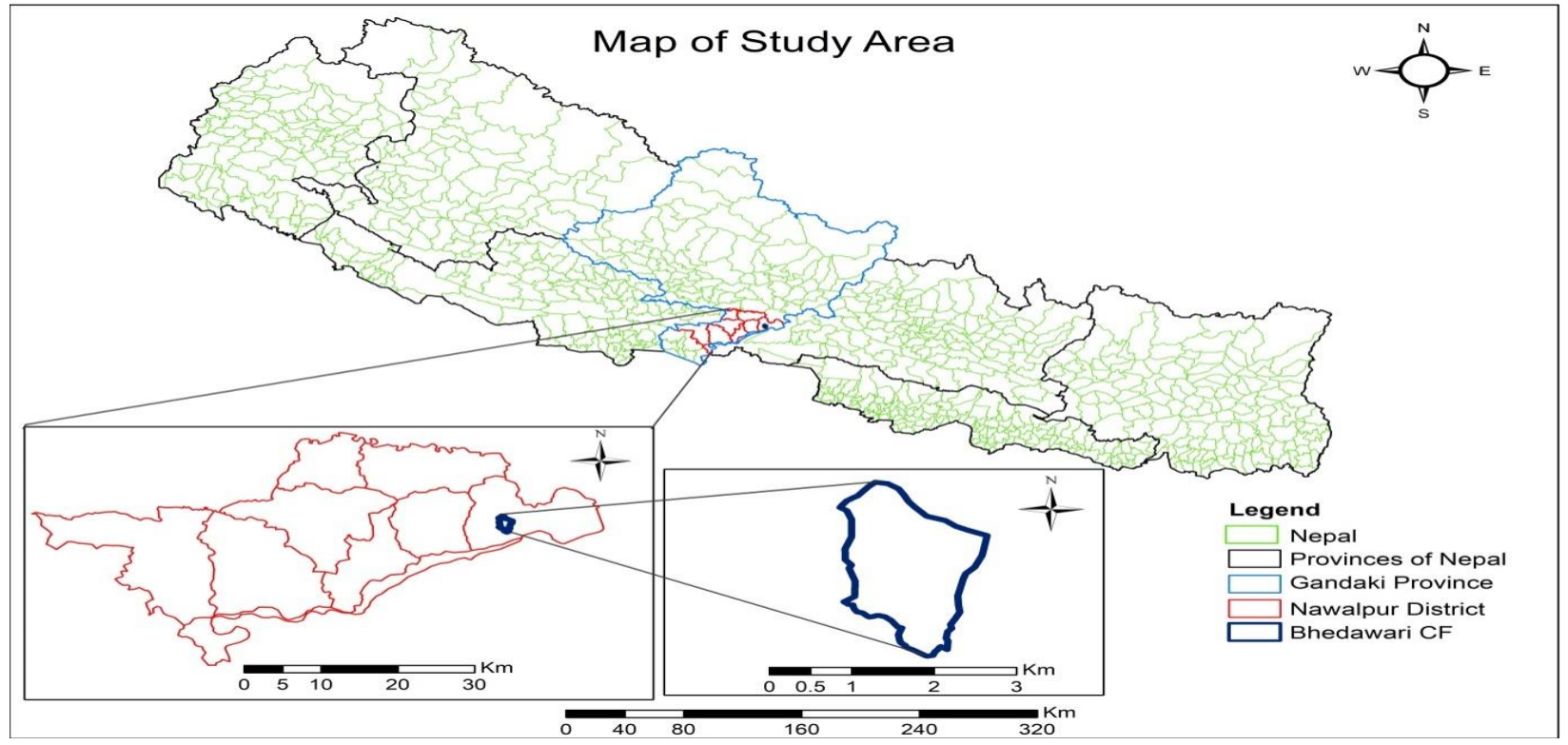

Figure 1: Map of the Study Area

\section{Soil Sample Collection}

The stratified random sampling method was adopted for this study. Two aspect classes (north and south) were the strata for the study. Soil samples were collected from 10 replicated sites of each aspect within the study area. In each sampling site, a pit of $30 \mathrm{~cm} \times 100 \mathrm{~cm}$ pit was dug, and undisturbed soil core samples were taken by a cylindrical core sampler $(5.5 \mathrm{~cm}$ diameter and 10 $\mathrm{cm}$ height) from the $0-10 \mathrm{~cm}, 10-20 \mathrm{~cm}$, and $20-30 \mathrm{~cm}$ soil depths for the determination of bulk density. The bulk soil samples were dried in oven, sieved through a $2 \mathrm{~mm}$ sieve and carefully stored before basic considerations. The samples were collected during March 2018.

\section{Bulk Density Analysis}

Soil bulk density was determined using core sampling method (Blake and Hartge, 1986). Oven dried $\left(\right.$ at $105{ }^{\circ} \mathrm{C}$ ) soil samples were used for moisture correction. Bulk density was calculated by the following formula: 
Bulk density $\left({\mathrm{g} . \mathrm{cm}^{-3}}^{-3}\right)=\left(\right.$ Oven dry weight of soil in ' $\mathrm{g}$ ') / (Volume of the soil in ' $\left.\mathrm{cm}^{3 \prime}\right)$

Where,

Volume of the soil $=$ Volume of core - Volume of the stone

\section{Estimation of Soil Organic Carbon}

Soil organic carbon percent was determined by the titration method developed by Walkley and Black (1934). The Soil Organic Carbon content percent was calculated as per following:

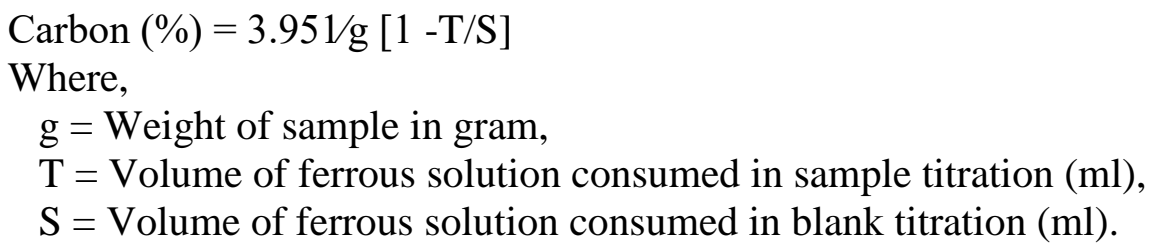

Total soil organic carbon was then calculated (Chhabra, Palria and Dadhwal, 2003)

$\mathrm{SOC}=\rho \times \mathrm{d} \times \% \mathrm{C}$

Whereas,

$\mathrm{SOC}=$ soil organic carbon stock per unit area $\left(\right.$ ton $\left.\mathrm{ha}^{-1}\right)$,

$\rho=$ soil bulk density $\left(\mathrm{Kg} / \mathrm{m}^{3}\right)$,

$\mathrm{d}=$ soil depth $(\mathrm{m})$, and

$\% \mathrm{C}=$ carbon concentration $(\%)$

\section{Results and Discussion}

\section{Bulk Density}

Bulk density (BD) varies with respect to depths in the soil. The range of BD in northern and southern aspects upto $30 \mathrm{~cm}$ depth of Bhedawari Community Forest is given in Table 1. The minimum BD $\left(1.35 \pm 0.06 \mathrm{~g} . \mathrm{cm}^{-3}\right)$ was found at the topsoil $(0-10 \mathrm{~cm})$ while maximum BD $(1.59 \pm$ $\left.0.07 \mathrm{~g} . \mathrm{cm}^{-3}\right)$ was at $20-30 \mathrm{~cm}$ in the southern aspect. The finding is similar with Shrestha (2009) who reported that there was a gradual increase in BD with increase in depths in both broad leaved (Shorea and Schima-Castanopsis) forests. Ghimire, Kafle and Bhatta (2018) also reported that BD value of soil also increases with increase in depths of soil layers in different land uses in Churia range, Nepal. BD at 10-20 cm profile in the north aspect differs slightly than other depths; this may be due to presence of tree root zone.

Table 1: Average Bulk density $\left(\mathrm{g} \cdot \mathrm{cm}^{-3}\right)$ at various depths

\begin{tabular}{|c|c|c|c|c|c|c|}
\hline \multirow{2}{*}{$\begin{array}{c}\text { Depth } \\
(\mathrm{cm})\end{array}$} & \multicolumn{3}{|c|}{ Northern Aspect } & \multicolumn{3}{c|}{ Southern Aspect } \\
\cline { 2 - 7 } & Mean & S.D. & S.E. & Mean & S.D. & S.E. \\
\hline $0-10$ & 1.43 & 0.32 & 0.10 & 1.35 & 0.19 & 0.06 \\
\hline $10-20$ & 1.37 & 0.33 & 0.11 & 1.55 & 0.23 & 0.07 \\
\hline $20-30$ & 1.51 & 0.31 & 0.10 & 1.59 & 0.23 & 0.07 \\
\hline
\end{tabular}


Doi: https://doi.org/10.33002/nr2581.6853.02125

\section{Soil Organic Carbon Percentage (SOC \%)}

The SOC percentage was higher at the upper layers and gradually decreased in the soil depth. Table 2 shows the depth wise distribution of SOC stock in different aspects. The maximum SOC \% (1.20 $\pm 0.14)$ was found at the topsoil $(0-10 \mathrm{~cm})$ in the northern aspect and minimum SOC \% $(0.47 \pm$ 0.08 ) at the depth of $20-30 \mathrm{~cm}$ in the southern aspect (Table-2). The soil organic carbon in the forest depends upon forest types, climate, moisture, temperature, soil organic matter and types of soil. Higher SOC percent in upper layer is due to high soil organic matter content and less degraded organic matter. Top layer of most of the soils contains carbon between $0.3 \%$ and $11.5 \%$ in the 20 $\mathrm{cm}$ surface mineral soil (Perry, 1994 cited in Lal, 2005). Neupane (2017) recorded maximum SOC $\%$ being $1.09 \%$ in $0-10 \mathrm{~cm}$ and minimum being $0.65 \%$ in $20-30 \mathrm{~cm}$ depth in Kalika Community Forest of Chitwan district which is also a Churia broad leaved forest. This supports the result that with increase in the depths soil organic carbon percentage decreases.

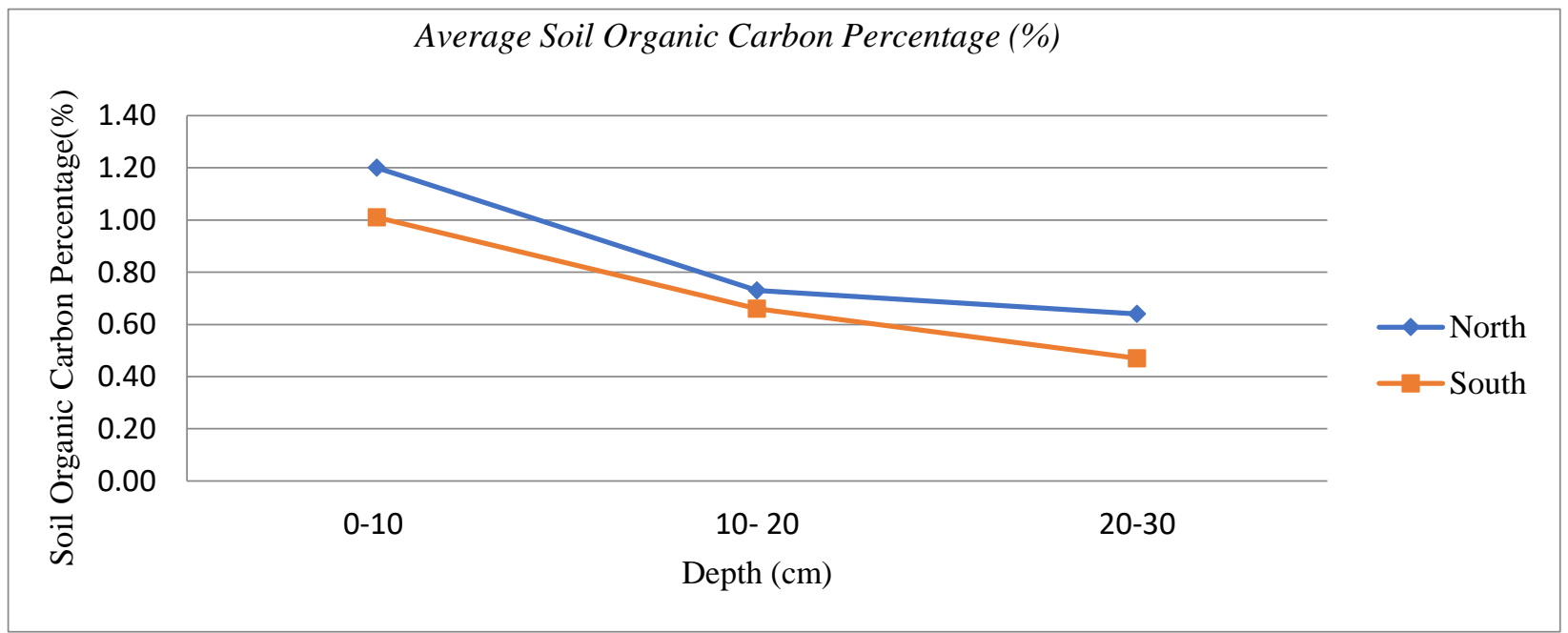

Figure 2: Average Soil Organic Carbon Percentage at various depths

Table 2: Average Soil Organic Carbon Percentage at various depths

\begin{tabular}{|c|c|c|c|c|c|c|}
\hline \multirow{2}{*}{$\begin{array}{c}\text { Depth } \\
(\mathrm{cm})\end{array}$} & \multicolumn{3}{|c|}{ Northern Aspect } & \multicolumn{3}{c|}{ Southern Aspect } \\
\cline { 2 - 7 } & Mean & S.D. & S.E. & Mean & S.D. & S.E. \\
\hline $0-10$ & 1.20 & 0.43 & 0.14 & 1.01 & 0.35 & 0.11 \\
\hline $10-20$ & 0.73 & 0.43 & 0.14 & 0.66 & 0.25 & 0.08 \\
\hline $20-30$ & 0.64 & 0.49 & 0.15 & 0.47 & 0.26 & 0.08 \\
\hline
\end{tabular}

\section{Soil Organic Carbon Stock}

It was found that with increase in the soil depth, SOC stock gradually decreases. Distribution of SOC stock in different soil profile is shown in Table 3. The maximum SOC (16.94 $\pm 1.86 \mathrm{t} / \mathrm{ha})$ was found at the topsoil $(0-10 \mathrm{~cm})$ in the northern aspect and minimum SOC $(7.48 \pm 1.34 \mathrm{t} / \mathrm{ha})$ at the depth of 20-30 cm in the southern aspect. The total SOC stock of Bhedawari Community Forest was found to be $33.91 \mathrm{t} / \mathrm{ha}$. This finding is similar to the SOC stock of Churia region of Nepal as reported by DFRS (2015). SOC diminishes with the depth of the soil (Shrestha, 2009). Higher rate of deposition of forest leaf, litters, etc. may results to higher organic carbon stock in the top layer. 
Pandey and Bhusal (2016) reported that the SOC decreased with the increase in soil depth in Shorea robusta forests of hills and Terai regions of Nepal. Also, Ghimire et al. (2018) reported higher SOC in top layer and decreased SOC with increased depth in Shorea robusta forests of Banaskhandi Community Forest, Makwanpur district. Thus, it is established that the results of this study were justified with previous findings that SOC decreases with increasing soil depths. The amount of SOC was higher in the northern aspect $(36.83 \pm 1.34 \mathrm{t} / \mathrm{ha})$ than in the southern aspect $(30.98 \pm 1.22 \mathrm{t} / \mathrm{ha})$, which was justified with studies that have reported higher SOC content on the north as compared to south-facing slope (Egli et al., 2009; Sharma et al., 2010). Similarly, Parjapati (2015) reported higher SOC in North-East aspect than in South-West aspect in Phulchoki Community Forest, Bhaktapur district.

Table 3: Average Soil Organic Carbon Stock at various depths

\begin{tabular}{|c|c|c|c|c|c|c|}
\hline \multirow{2}{*}{$\begin{array}{c}\text { Depth } \\
(\mathrm{cm})\end{array}$} & \multicolumn{3}{|c|}{ North } & \multicolumn{3}{c|}{ South } \\
\cline { 2 - 7 } & Mean & S.D. & S.E. & Mean & S.D. & S.E. \\
\hline $0-10$ & 16.94 & 5.88 & 1.86 & 13.74 & 4.87 & 1.54 \\
\hline $10-20$ & 10.16 & 6.28 & 1.99 & 9.76 & 2.62 & 0.83 \\
\hline $20-30$ & 9.73 & 7.46 & 2.36 & 7.48 & 4.24 & 1.34 \\
\hline Total & 36.83 & & & 30.98 & & \\
\hline
\end{tabular}

The total soil carbon stock in Bhedawari Community Forest differs significantly in both Northern and Southern aspects with p value of 0.002 ( $\mathrm{p}<0.05)$. This correlates to Begum et al. (2010) who found significant difference in average SOC, which was higher on the northern aspect than the southern aspect.

\section{Conclusion}

The total SOC stock was $33.91 \mathrm{t} / \mathrm{ha}$, which is decreasing with increasing depths. The total SOC stock was found to be higher in Northern (36.83 t/ha) aspect than that of Southern aspect (30.98 t/ha). Despite similarity in vegetation, low light intensity (temperature) may be contributed in higher SOC storage in north. North-facing sites are usually cool and moist and contain higher amounts of organic carbon and organic matter, higher abundance and diversity of soil fauna, whereas south-facing slopes are usually hot and dry, prone to erosion and are depleted in SOC. Hence, soil carbon sequestration through enhanced community managed forest is a good strategy to mitigate the increasing concentration of atmospheric $\mathrm{CO}_{2}$.

\section{Acknowledgement}

We gratefully acknowledge the Faculty of Forestry, Agriculture and Forestry University, Nepal for providing fund for this research work. We would like to express our deepest acknowledgement and heartfelt gratitude for all the concern people and institutions for their significant contribution and support for the successful completion of this research work. 
Doi: https://doi.org/10.33002/nr2581.6853.02125

\section{References}

Begum, F., Bajracharya, R.M., Sharma, S. and Sitaula, B.K (2010). Influence of slope aspect on soil physico-chemical and biological properties in the mid hills of central Nepal. International Journal of Sustainable Development \& World Ecology, 17(5): 438-443.

Blake, G.R. and Hartge, K.H. (1986). Bulk Density. In: A. Klute (ed.), Methods of Soil Analysis: Part 1-Physical and Mineralogical Methods, SSSA Book Ser. 5.1., 2nd ed. Madison, WI: SSSA, ASA, pp. 363-375. https://doi.org/10.2136/sssabookser5.1.2ed. c13

Campbell, A., Miles, L., Lysenko, I., Hughes, A. and Gibbs, H. (2008). Carbon storage in protected areas: Technical report. Cambridge, UK: The United Nations Environment Programme World Conservation Monitoring Centre (UNEP-WCMC).

Chhabra, A., Palria, S. and Dadhwal, V.K. (2003). Soil organic carbon pool in Indian forests. Forest Ecology and Management, 173(1-3):187-199.

DFRS (2015). State of Nepal's Forests. Forest Resource Assessment (FRA) Nepal. Kathmandu, Nepal: Department of Forest Research and Survey (DFRS).

Egli, M., Sartori, G., Mirabella, A., Favilli, F., Giaccai, D. and Delbos, E. (2009). Effect of north and south exposure on organic matter in high alpine soils. Geoderma, 149(1-2), pp.124-136.

Ghimire, P., Bhatta, B., Pokhrel, B., Kafle, G. and Paudel, P. (2018). Soil organic carbon stocks under different land uses in Chure region of Makawanpur district, Nepal. SAARC Journal of Agriculture, 16(2): 13-23.

Ghimire, P., Kafle, G. and Bhatta, B. (2018). Carbon stocks in Shorea robusta and Pinus roxburghii forests in Makawanpur district of Nepal. Journal of AFU (Vol 2): 241-248, Agriculture and Forestry University, Chitwan, Nepal.

Jobbágy, E.G. and Jackson, R.B. (2000). The vertical distribution of soil organic carbon and its relation to climate and vegetation. Ecological Applications, 10(2): 423-436.

Lal, R. (2005). Forest soils and carbon sequestration. Forest Ecology and Management, 220(1-3): 242-258.

Lorenz, K. and Lal, R. (2005). The depth distribution of soil organic carbon in relation to land use and management and the potential of carbon sequestration in subsoil horizons. Advances in agronomy, 88: 35-66.

Maplecroft (2010). Maplecroft: South Asia Most at Risk from Climate Change, Scandinavia safest. [online]

Available

at: http://www.preventionweb.net/english/professional/news/v.php?id=16004 [Accessed 17 June, 2018]

MoEnv (2012). Mountain Environment and Climate Change in Nepal: National Report prepared for the International Conference of the Mountain Countries on Climate Change, 5-6 April 2012. Kathmandu, Nepal: Ministry of Environment, Government of Nepal.

Neupane, T. (2017). Comparative Study of Soil Organic Carbon Stock of Community Forest and Protected Area Forest. B.Sc. Forestry Lee Report. Agriculture and Forestry University, Faculty of Forestry, Hetauda, Nepal.

Pandey, H.P. and Bhusal, M. (2016). A comparative study on carbon stock in Sal (Shorea robusta) forest in two different ecological regions of Nepal. Banko Janakari, 26(1): 24-31.

Parjapati, S.R. (2015). Effects of Geographical Aspect on Carbon Stock in Broadleaved Mixed Natural Forest: A Case Study of Bhaktapur District. A Thesis submitted in partial fulfillment of the requirements for the Degree of Bachelor of Science in Forestry. Tribhuvan University, Kathmandu Forestry College, Kathmandu, Nepal. 
Parry, M., Parry, M.L., Canziani, O., Palutikof, J., Van der Linden, P. and Hanson, C. (eds.) (2007). Climate change 2007-impacts, adaptation and vulnerability: Working group II contribution to the fourth assessment report of the IPCC (Vol. 4). Cambridge: Cambridge University Press.

Schrumpf, M., Schulze, E.D., Kaiser, K. and Schumacher, J. (2011). How accurately can soil organic carbon stocks and stock changes be quantified by soil inventories? Biogeosciences, 8(5): 1193-1212.

Sharma, C.M., Baduni, N.P., Gairola, S., Ghildiyal, S.K. and Suyal, S. (2010). Effects of slope aspects on forest compositions, community structures and soil properties in natural temperate forests of Garhwal Himalaya. Journal of Forestry Research, 21(3): 331-337.

Sheikh, M.A., Kumar, M. and Bussmann, R.W. (2009). Altitudinal variation in soil organic carbon stock in coniferous subtropical and broadleaf temperate forests in Garhwal Himalaya. Carbon Balance and Management, 4(1): 6.

Shrestha, B.P. (2009). Carbon sequestration in broad leaved forests of mid-hills of Nepal: A case study from Palpa district. The Initiation, 3: 20-29.

Walkley, A. and Black, I.A. (1934). An examination of the Degtjareff method for determining soil organic matter, and a proposed modification of the chromic acid titration method. Soil Science, 37(1): 29-38. 